\title{
Finlandiya, Japonya, Kore, Çin (Şangay) ve Türkiye'deki İngilizce Dersi Öğretim Programlarının Karşılaştırmalı Olarak İncelenmesi
}

\section{A Comparative Analysis of the English Language Curricula in Finland, Japan, Korea, China (Shanghai) and Turkey}

\section{Yusuf DEMIR* Mustafa YAVUZ ${ }^{* *}$}

Öz: Uluslarası ortak dil (lingua franca) olarak İngilizce bilimde, teknolojide, ticarette, küresel organizasyonlarda en çok kullanılan dil olarak öne çıkmıştır ve bu bağlamda önemi artık yadsınamaz bir noktadadır. İngilizce'nin bu önemini gün geçtikçe daha iyi kavrayan devletler artık eğitim politikalarına da bunu yansıtma ihtiyacı hissetmişlerdir. Bu noktada ülkelerin hazırlamış oldukları İngilizce öğretim programlarının özellikleri, İngilizce öğretimine verdikleri öneme dair bizlere ipuçları vermesi açısından önemlidir ve bu çalışma için bir çıkış noktası olmuştur. Dolayısıyla da İngilizce öğretim programlarına küresel bir bakış açısı kazandırmak bu çalışmanın amacını oluşturmaktadır. Bu amaçla OECD (Ekonomik Kalkınma ve İşbirliği Örgütü) tarafından son olarak 2012'de yapılan PISA'nın (Uluslarası Öğrenci Değerlendirme Programı) okuma testi sonuçları temel alınmış, İngilizce'yi yabancı dil olarak öğreten, PISA'daki okuma testinde en yüksek puanı alan ilk dört ülke olan Çin (Şangay), Kore, Finlandiya ve Japonya ile ortalamanın altında kalan Türkiye'nin İngilizce öğretim programları karşılaştırmalı olarak ele alınmıştır. Doküman incelemesi yoluyla elde edilen verilerin çözümlenmesi sonucunda, ülkelerin İngilizce öğretim programlarındaki hedeflerin genellikle benzerlikler gösterdiği tespit edilmiş̧ir. Bunun yanı sıra içerik, eğitim durumları ve sınama durumları bakımından da programlar arasında benzerliklerin ve birtakım farklı uygulamaların söz konusu olduğu görülmüştür.

Anahtar sözcükler: İngilizce öğretim programı, karşılaştırmalı eğitim, eğitim politikası

Abstract: As a lingua franca, the English language has widely and chiefly been used in science, technology, trade, business and in the global organizations and its importance has already been acknowledged globally. Governments, with a better grasp of the importance of English day by day, have felt the need to include the teaching of English more than before in their educational policies. At this point, features of English language curricula prepared by governments are important in terms of providing cues for revealing the importance given to English language teaching. This study aims to present a global point of view on the English language curricula examined. For this purpose, reading test scores of the OECD's latest PISA were taken into account and English language curricula of the top four ranking EFL countries (Finland, Japan, Korea, China-Shanghai) were analyzed and compared, by adding to the comparison list a low-ranking country, Turkey. The data obtained through document analysis made clear that on the whole, there exist similarities in the objectives of English language curricula of the five countries. Moreover, similarities and some differing practices were identified with regards to the content, teaching/learning process and evaluation.

Keywords: English language curriculum, comparative education, educational policy

\footnotetext{
* Okutman., Selçuk Üniversitesi, Ilgın Meslek Yüksek Okulu, Konya, yusufdemir@selcuk.edu.tr

** Doç. Dr., Necmettin Erbakan Üni., A. Keleşoğlu Eğit. Fak., Eğitim Bilim. Böl., Konya, mustafayavuz@konya.edu.tr
} 
Gün geçtikçe ortaya çıan teknolojilerle küçülen dünyada hiç şüphesiz iletişimin önemi her geçen gün artmaktadır. Artık teknoloji dünyanın dört bir tarafından insanları anlık iletişim imkânlarıyla bir araya getirmektedir. Bu küresel iletişimi sağlamada İngilizce, ana dilleri farklı olan farklı milletlere mensup insanları buluşturma noktasında adeta geçerli bir pasaport konumuna gelmiştir.

Kachru, (1985) yaklaşık 30 sene önce, dünyada İngilizce'yi ana dil olarak konuşanların 320 ile 380 milyon arasında, ikinci ya da yabancı dil olarak konuşanların sayısının da 250 ile 380 milyon arasında olduğunu söylemiş ve bu dengenin ileride değişebileceğini “İngilizce'nin yayılması bu hizda devam ederse, 2000 yllına kadar Ingilizce'yi yabancı dil olarak kullananların sayısı, ana dil olarak Ingilizce konuşanların sayısını geçecektir" cümlesiyle ifade etmiştir. Kachru tahmininde yanılmamıştı ve Harmer, (2007) bu yayılmanın Kachru'nun tahmin ettiğinden de daha hızlı olduğunu belirtmiştir. Tahminler değişkenlik göstermektedir, fakat Rajagopalan, (2004) ana dil olarak İngilizce'yi konuşanların yabancı dil olarak konuşanlara oranını 1:2, Crystal, (2003) ise 1:3 olarak açıklamıştır ve bu oran gitgide büyüyecek gibi görünmektedir. McKay'in (2000), dünyada İngilizce'yi ana dili olarak ya da ana dili gibi konuşan yarım milyardan fazla insan olduğunu ve belki de bir milyar kadar kişinin de İngilizce öğrenmekte olduğunu belirtmesi de göz önünde bulundurulacak olursa, İngilizce'nin dünyadaki yaygınlığı ve önemi daha anlaşılır hale gelecektir.

Dünya dilleri arasında başı çeken ve geri dönülemez bir önem atfedilmiş olan İngilizce artık insanlar için bir lüks olmaktan çıkmış, öğrenimi ihtiyaç haline gelmiştir. Bu da devletlerin dil eğitim politikalarını sürekli yenileme ihtiyacını doğurmuştur. Her geçen yıl İngilizce öğrenme yaşı ülkelerce daha da aşağıya çekilmektedir.

Birçok ülke olanakları doğrultusunda İngilizce'ye maruz kalmaları için öğrencilerini Kachru’nun (1985) iç çember olarak nitelediği İngilizce'yi ana dil olarak konuşan ülkelere göndermektedir. Aynı şekilde öğretmenlerin de meslekî gelişimleri kapsamında İngilizce konuşan ülkelere gönderilmesi yaygınlaşmaktadır. Elbette ki bu olanaklar bütün öğrencilere ve öğretmenlere sağlanamayacağına göre verimli ve çağdaş yapılanmaya uygun İngilizce öğretim programlarının hazırlanması uygulanabilirlik açısından şarttır.

Devletlerce hazırlanan öğretim programlarına baktığımız zaman her ne kadar farklı adlar taşısalar da hepsinin amacı mevcut şartlar dahilinde öğrenciyi en verimli noktaya taşımaktır. Hazırlanan hiçbir programın son hâli olduğu kabul edilemez, zira küreselleşme devam ettikçe programların da yenilenmesi esastır. Bazı ülkelerin hazırladıkları programlar bir öncekine göre köklü değişiklikler içerirken, bazı ülkelerin programları da bir öncekinin değiştirilmiş ve kısmen revize edilmiş şekliyle karşımıza çıkmaktadır.

\section{Finlandiya, Japonya, Kore, Çin (Şangay) ve Türkiye’deki Öğretim Programlarının Yapılanmasına Genel Bir Bakış}

Finlandiya Eğitim Sistemi’nde öğretim programları çekirdek (core curriculum) program anlayışıyla geliştirilmiştir. Bu program ulusal bir çerçeve niteliğinde olup, bölgesel olarak okullar bu çerçeveyi temel alarak amaçları doğrultusunda kendi öğretim programlarını hazırlayabilmektedir. Yedi yaşından başlayıp dokuz yıl devam eden (ISCED 1 VE ISCED 2) temel eğitim için hazırlanan çerçeve program, genel hedefleri ve programlar arası temel konu içeriklerini barındırmaktadır. Okullarda verilen derslerin hedefleri ve temel içerikleri, tek çatı altında temel eğitim için hazırlanan bu çerçeve programda bulunmaktadır. Aynı şekilde yabancı dil olarak İngilizce dersinin hedefleri, konu içerikleri, belirlenen dil yeterlilik düzeyleri de bu ulusal çekirdek programda mevcuttur. Bu çekirdek program öğrencilere yönelik sosyal hizmetlerin 
hedeflerini, temel prensiplerini ve okul-ev dayanışmasının niteliklerini de belirlemiştir.

Japonya'da Eğitim, Kültür, Bilim, Spor ve Teknoloji Bakanlığı okul öncesi eğitimden (ISCED 0) başlayarak ISCED 3 düzeyine kadarki okulların kendi öğretim programlarını yapmalarına dayanak oluşturan temel standartları belirler. Böylelikle ülke genelinde eğitimde standardizasyon sağlamayı amaçlar. Bütün öğretim kademelerine ait hedefler, programlar, eğitim yapılacak hafta sayısı ve alınacak dersler Okul Eğitimi Yasası'nda bulunmaktadır. Her bir dersin hedef ve içeriklerine ise bu yasaya uygun olarak düzenlenen öğretim programlarında yer verilmiştir. Son olarak ISCED 2 düzeyinin bütün basamaklarına ait öğretim programlarının ilkeleri ülke genelinde 2012'den itibaren uygulanmaya başlamıştır.

Kore'deki Ulusal Öğretim Programı eski adı Eğitim, Bilim ve Teknoloji Bakanlığı olan Kore Eğitim Bakanlığı'nca düzenlenir. ISCED 1, ISCED 2 ve ISCED 3 düzeyindeki eğitimin hedeflerini, içeriğini ve ögretimin işleyişini düzenler ve okulların uygulamak zorunda oldukları standartları belirler. Program aynı zamanda derinlemesine öğrenmeyi sağlamak için bütün derslere ait standartlar belirlemiştir. Programda öğrencilerin farklı öğrenme alanlarına yönelik öğrenme ve öğretme stilleri de vurgulanmıştır. Kore'deki ulusal program çekirdek program özelliğine sahiptir. Bu program, İngilizce dersinin de içinde bulunduğu konu disiplinlerinden, seçmeli etkinliklerden ve program dışı etkinliklerden oluşmaktadır. Kore'de günümüzde yürürlükte olan öğretim programı 7. öğretim programı olarak bilinmektedir. 1997'de geliştirilen mevcut program 2000 yılında yürürlüğe konmuştur ve eğitimdeki küresel gelişmeler göz önünde bulundurularak düzenli olarak revize edilmektedir.

Çin Halk Cumhuriyeti'nin kendi öğretim programını yapmasına imkân tanıdığı birkaç belediyesinden veya bölgesinden biri olan Şangay'da dokuz yll süren temel eğitimin idaresi "İki Kademeli Yönetim" adı verilen sistemle yürütülmektedir. Bu sisteme gore Şangay Belediyesi Hükümeti ile Şangay Belediyesi Eğitim Komisyonu eğitim politikalarını belirlemekten, eğitim denetiminden ve okulların performansını değerlendirmekten sorumludur. Çin Milli Eğitim Bakanlığı'nın onayı ile Şangay ve diğer bölgesel yönetim birimleri kendi öğretim programlarını ve program uygulama standartlarını geliştirebilmektedirler. Şangay'da resmi okullar bulundukları sosyal çevreyi, ekonomik şartları, okul geleneklerini ve öğrencilerin ilgilerini ve ihtiyaçlarını dikkate alarak uygun öğretim programını seçebilir ya da geliştirebilmektedirler. Şangay'da 1988 ve 1998 'de birinci ve ikinci aşama olarak nitelendirilen öğretim programı reformları başlatılmıştır. Öğretim programı reformunun ikinci aşaması sekiz öğrenme alanını temel almıştır. Bunlar: dil ve edebiyat, matematik, doğa bilimleri, sosyal bilimler, teknoloji, sanat, beden eğitimi ve uygulamalı eğitimdir. Uygulamalı eğitim, sosyal hizmetleri kapsamakla beraber öğrencileri toplumla kaynaştırmayı amaçlamaktadır. Şangay'daki mevcut öğretim programı üç kategoriye ayrılmıştır. Temel öğretim programı; zorunlu derslerden oluşur ve bütün öğrenciler tarafından alınması gereken dersleri kapsar. Genişletilmiş öğretim programı; öğrencilerin farklı ilgi ve yeteneklerine yöneliktir ve ağırlıkla seçmeli derslerden oluşur. Araştırma-odaklı öğretim programı ise program dışı etkinliklerden oluşur ve öğrencilerin öğrenmeyi öğrenmelerine katk1 sağlamayı, bağımsız araştırma yapmalarını teşvik etmeyi ve öğrendiklerini uygulamaya koymalarını amaçlar.

Türkiye'de öğretim programlarını Milli Eğitim Bakanlığı'na bağlı Talim ve Terbiye Kurulu hazırlamaktadır. Okul öncesi eğitimden (ISCED 0) itibaren zorunlu eğitimin son kademesindeki (ISCED 3) dersler de dahil olmak üzere bütün kademelerdeki derslerin öğretim programları bu kurulca hazırlanır. Kurulca hazırlanan öğretim programları merkezî niteliktedir. Ülke genelindeki bütün okullarda aynı öğretim programları yürütülür. Okullar, kendi programlarını geliştirme ve uygulama esnekliğine sahip değildir. 
Çalışmanın Problemi: Mevcut çalışma beş farklı ülkedeki (Finlandiya, Japonya, Kore, Çin (Şangay) ve Türkiye) İngilizce öğretim programlarını karşılaştırmalı olarak değerlendirerek genel durumu yansıtmayı amaçlamaktadır. Karşılaştırılan ülkelerin "İngilizce ögretim programları arasında hedef, içerik, eğitim durumları ve sınama durumları bakımından benzerlik ve farklılıklar var mıdır?” varsa "Nelerdir?” sorularına yanıt aranmaya çalışılmıştır. Karşılaştırmalı eğitimin toplumlar arasında eğitimdeki sorunların nedenlerini açığa vurması, diğer ülkelerde uygulanan sistemlerin aksayan yönlerini göstererek eldekini iyiye götürmesi, eğitimsel uygulamaları zenginleştirmeye dair fikir vermesi gibi özellikleri de bu karşılaştırmalı çalışmanın esin kaynağı olmuştur.

\section{Yöntem}

Çalışmanın yapısına uygun olarak veriler "doküman incelemesi” yöntemiyle elde edilmiştir. Veriler, bu yöntemin beş karakteristik aşaması olan (1) dokümanlara ulaşma, (2) orijinalliğin kontrol edilmesi, (3) dokümanların anlaşılması, (4) verinin analiz edilmesi ve (5) verinin kullanılması (Yıldırım, \& Şimşek, 2003) aşamaları takip edilerek irdelenmiştir. Dokümanlara ülkelerin eğitim bakanlıklarının ve program geliştirme departmanlarının internet sitelerinden ulaşılmıştır. Bunun yanı sıra, Avrupa Eğitim Bilgi Ağı (Eurydice) ve Avrupa Konseyi’nin sitelerindeki dokümanlardan da faydalanılmıştır. Sınıf içi uygulamalar ve sınav sistemlerine ilişkin anlayış kazandırması bakımından dünyaca tanınmış uluslararası yayınevlerinden çıkan bazı kitap ve makaleler de incelenmiştir.

\section{Bulgular ve Yorum}

Alanyazında formal eğitimde yabancı dil öğretimine başlamada en ideal yaş aralığının ne olduğuna dair bir konsensus sağlanamamıştır. Krashen, Long, \& Scarcella (1979) yabancı dil öğrenimine erken başlamanın dili daha iyi öğrenmeyi sağladığını söylemektedir. Benzer şekilde Kuhl (2000), ve Ellis (2005), yabancı dil öğrenimine erken başlayan çocukların, geç başlayanlara göre daha başarılı ve verimli öğreneceklerini ifade etmiştir. Öte yandan, Dörnyei (2009), daha erkenin daha iyi olması durumunun sadece natüralist ikinci dil ortamlarında geçerli olduğunu, yani ikinci dil öğrenenlerin dilin konuşulduğu ülkedeki yabancı dile aşırı maruz kalması ve o dilin ana dil kullanıcılarıyla yoğun bir etkileşimi durumunda bu genellemenin ancak kabul edilebileceğini ifade etmektedir. Dörnyei (2009), okulda bir ders olarak yabancı dil eğitimi söz konusu olduğunda erken başlamanın daha iyi olmadığını söylemiş, yine bu görüşe paralel olarak da Lightbown, \& Spada (2006), yaşça büyük olan öğrencilerin daha küçük olanlara kıyasla okulda yabancı dil için ayrılan sınırlı zamanı kullanmada daha etkili olduklarını savunmuşlardır.

Cenoz, (2003), Munoz (2006), yaş faktörünün yabancı dil başarısına etkisini araştırmak için İspanya bağlamında iki farklı çalışma yürütmüş, bu çalışmaların her ikisinde de yaşça daha büyük olan grupların, daha küçük olanlara göre daha başarılı olduğu ve daha hızlı öğrenme gerçekleştirdikleri gözlenmiştir. Fakat yaş-dil öğrenme ilişkisinde kesin olarak bir yargıya varmak ve küresel bağlamda geçerli bir doğruya ulaşmak için dünya genelinde birçok ülkede öğrenci, öğretmen, kullanılan yöntemler ve ders materyalleri, ölçme-değerlendirme vs. gibi pek çok değişken de göz önünde bulundurularak daha uzun süreli boylamsal araştırmalara ihtiyaç vardir.

Yukarıda ifade edilen görüşler devletlerin dil eğitim politikalarına farklı olarak yansımış ve okullarda yabancı dil öğrenmeye başlama yaşını belirlemede etkili olmuştur. Dolayısıyla, genel bir kabul olarak yabancı dil öğretimine daha erken yaşta başlayan ülkelerin en azından İngilizce öğretimini daha fazla önemsedikleri söylenebilir. 
Tablo 1. Finlandiya, Japonya, Kore, Çin (Şangay) ve Türkiye'de Resmi Okullarda İngilizce Dersine Başlama Kademesi

\begin{tabular}{|c|c|}
\hline Finlandiya & $\begin{array}{l}\text { Öğrencilerin neredeyse tamamının birinci zorunlu yabancı dil olarak seçtiği İngilizce eği- } \\
\text { timi ilkokul 3'te ve A1 }{ }^{*} \text { dili olarak başlamaktadır. İlkokul } 1 \text { ya da 2'de İngilizce eğitimine } \\
\text { başlayan bazı okullar olmakla beraber, İngilizce'ye } 3 \text {. sınıftan önce başlamak her geçen yıl } \\
\text { gitgide yaygınlaşmaktadır. }\end{array}$ \\
\hline Japonya & $\begin{array}{l}\text { Zorunlu İngilizce dersi resmî olarak ISCED 2'nin birinci yılında başlamaktadır. Ancak } \\
\text { Nisan 2011'de uygulamaya konulan ilkokullara yönelik program ilkeleri uyarınca yabanc1 } \\
\text { dilde iletişim etkinlikleri ilkokul 5. ve } 6 \text {. sınıflarda zorunlu hale gelmiştir. Bu etkinlikler, } \\
\text { bir ders olarak verilmekten ziyade iletişime yönelik olumlu tutum geliştirmeyi amaç- } \\
\text { lamaktadır. }\end{array}$ \\
\hline Kore & İlkokul 3. Sınıftan itibaren zorunlu İngilizce dersi verilmektedir. \\
\hline $\begin{array}{l}\text { Çin } \\
\text { (Şangay) }\end{array}$ & $\begin{array}{l}\text { İngilizce'nin ilkokul 3. sınıftan itibaren zorunlu olduğu Çin'in aksine, Şangay'da zorunlu } \\
\text { İngilizce dersleri ilkokul 1'de başlar. Böylelikle öğrencilere en az } 9 \text { yıllı zorunlu İngilizce } \\
\text { dersi vermek amaçlanmıştır. }\end{array}$ \\
\hline Türkiye & $\begin{array}{l}\text { 2013-2014 eğitim-öğretim yılından itibaren zorunlu İngilizce derslerinin ilkokul 2'de baş- } \\
\text { laması kararlaştırılmıştır. }\end{array}$ \\
\hline
\end{tabular}

* Finlandiya Ulusal Eğitim Komisyonu, okullarda A ve B olmak üzere iki adet yabancı dil seçme sistemi belirlemiştir. A1 zorunlu eğitimin alt basamaklarında uygulanan zorunlu yabancı dil dersini; A2 zorunlu eğitimin alt basamaklarında uygulanan isteğe bağlı yabancı dil dersini; B1 zorunlu eğitimin üst basamaklarında uygulanan zorunlu yabancı dil dersini; B2 ise zorunlu eğitimin üst basamaklarında uygulanan seçmeli yabancı dil dersini ifade etmektedir.

\section{İngilizce Öğretim Programlarının Hedefler Bakımından Karşılaştırılması}

Aşağıdaki tabloda, programın dört temel unsurundan biri olan hedefler bakımından Finlandiya, Japonya, Kore, Çin (Şangay) ve Türkiye İngilizce öğretim programları karşıllaştırılmıştır.

Tablo 2. ISCED 2 Düzeyinde İngilizce Öğretim Programlarının Hedefler Açısından Karşılaştırılması

\begin{tabular}{|l|l|}
\hline & $\begin{array}{l}\text { İngilizce öğretim programındaki genel hedefler } \\
\text { - Yabancı dilde iletişim kurabilecek yeterlik sağlamak, } \\
\text { - Öğrencileri dil becerilerini kullanmaya alıştırmak, } \\
\text { - Diğer kültürlere ait insanların yaşam tarzlarını anlamalarını ve değer vermelerini sağlamak. } \\
\text { ISCED } 2 \text { Düzeyindeki Hedefler } \\
\text { Dil yeterliği açısından hedefler } \\
\text { Öğrencilerin; } \\
\text { - Kendileri ve yakın çevreleri hakkında temel bilgileri aktarmayı öğrenmeleri, ihtiyaç duydu- } \\
\text { ğunda karşısındaki konuşmacının yardımını alarak normal günlük konuşma durumlarında iletişim } \\
\text { kurabilmeleri, } \\
\text { - Durumsal bağlantılar yardımıyla günlük hayattaki olayları anlatan yazılı metinleri ve konuşma- } \\
\text { ları anlayabilmeleri, } \\
\text { - Günlük ihtiyaç ve deneyimlerle bağlantılı öngörülebilir ve bildik durumlara ilişkin kısa iletiler } \\
\text { yazmayı öğrenmeleri hedeflenmektedir. } \\
\text { Kültürel beceriler açısından hedefler } \\
\text { Öğrencilerin; } \\
\text { - Hedef dilin konuşulduğu bölgedeki yaşam tarzını anlamaya başlamaları, } \\
\text { - Günlük konuşmalarda hedef kültüre özgü bir tarzda, hedef dilin kültürünün temsilcileriyle } \\
\text { iletişim kurmayı öğrenmeleri beklenmektedir. } \\
\text { Öğrenme Stratejileri açısından hedefler } \\
\text { Öğrencilerin; } \\
\text { - Bilgi edinme araçlarını kullanmak gibi birtakım etkili çalışma yöntemlerini kullanmaları, } \\
\text { - Yabancı dilde ürettiklerini (output) gözlemleme ve düzeltmeleri, birtakım anlama ve iletişim } \\
\text { stratejilerini kullanarak dil becerilerindeki eksikliklerini telafi etmeleri, } \\
\text { - Çalışmalarını ve farklı alanlardaki dil becerilerini hedeflerle bağlantılı olarak değerlendirmeleri } \\
\text { amaçlanmaktadır. }\end{array}$ \\
\hline
\end{tabular}




\begin{tabular}{|c|c|}
\hline 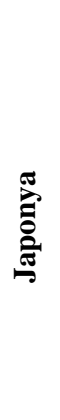 & $\begin{array}{l}\text { İngilizce öğretim programındaki genel hedefler } \\
\text { - Öğrencilerin konuşma, dinleme, okuma, yazma gibi temel iletişim becerilerini geliştirmek. } \\
\text { - Dil ve kültür anlayışlarını derinleştirmek. } \\
\text { - Yabancı dil aracılığıyla iletişime yönelik olumlu tutum geliştirmek. } \\
\text { ISCED } 2 \text { Düzeyindeki Hedefler } \\
\text { Öğrencilerin İngilizce konuşmaları dinlerken konuşmacının niyetini anlamalarını sağlamak. } \\
\text { - Öğrencilerin İngilizce'yi kullanarak kendi düşüncelerini sözlü olarak anlatmalarını sağlamak. } \\
\text { - Öğrencileri İngilizce'de okuma yapmaya alıştırmak ve İngilizce metni okurken yazarın söyle- } \\
\text { mek istediklerini anlamalarını sağlamak. } \\
\text { - Öğrencileri İngilizce'de yazmaya alıştırmak ve İngilizce'yi kullanarak kendi düşüncelerini yaz- } \\
\text { malarını sağlamak. }\end{array}$ \\
\hline 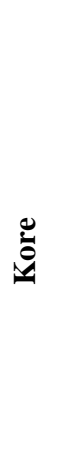 & $\begin{array}{l}\text { İngilizce öğgetim programındaki genel hedefler } \\
\text { - Günlük hayatta İngilizce'yi anlama ve kullanma yeteneğini geliştirmek. } \\
\text { - Günlük hayatta ve sıradan konular hakkında iletişim kurma yeteneğini geliştirmek. } \\
\text { - Öğrencilerin farklı kültürleri anlamalarını ve böylece kendi kültürünü daha düzgün bir şekilde } \\
\text { kavrayıp doğru bir bakış açısı kazanmalarını sağlamak. } \\
\text { ISCED } 2 \text { Düzeyindeki Hedefler } \\
\text { Öğrencilerin; } \\
\text { - İngilizce iletişim kurma ihtiyacını kavramaları, } \\
\text { - Günlük hayatta genel konular hakkında etkili iletişim kurmaları, } \\
\text { - İngilizce'ye dair çeşitli bilgileri kavrayıp uygulamaya dökmeleri, } \\
\text { - Farklı kültürlere değer vermeleri ve kendi kültürlerini İngilizce olarak tanıtmaları hedeflen- } \\
\text { mektedir. }\end{array}$ \\
\hline & $\begin{array}{l}\text { Şangay Öğretim Programları ve Materyal Geliştirme Komisyonu'nun (1999) tebliğine göre "Şan- } \\
\text { gay’da dünya standartlarında yabancı dil öğretim programları geliştirmek, Şangay Belediyesi'ni } \\
\text { uluslararası düzeyde bir metropole dönüştürmek için önkoşuldur”. } \\
\text { ISCED } 2 \text { Düzeyindeki Hedefler } \\
\text { - Öğrencilerin temel İngilizce bilgisi edinmelerine ve dinleme, konuşma, okuma ve yazma } \\
\text { yoluyla temel iletişim becerilerini geliştirmelerine yardımcı olmak. } \\
\text { - Gelecekteki çalışmaları ve İngilizce'yi kullanmaları açısından sağlam bir temel oluşturmak için } \\
\text { doğru çalışma alışkanlıkları geliştirmelerine ve temel dil öğrenme yöntemlerine hakim olmalarına } \\
\text { yardımcı olmak. } \\
\text { - İngilizce öğrenmeye ilgilerini artırmak ve İngilizce öğrenmeleri için doğru nedenleri telkin etmek. } \\
\text { - Öğgrencilerin analiz ve sentez yapma, gözlemleme, yaratıcılık ve hayal kurma becerilerini } \\
\text { geliştirmek. }\end{array}$ \\
\hline 莡 & $\begin{array}{l}\text { 2.-8. sınıflar için hazırlanan İngilizce öğretim programı yabancı dili özgün iletişim ortamlarında } \\
\text { kullandırtmayı, öğrencilerin İngilizce'yi bir iletişim aracı olarak tecrübe etmelerini, farklı ihtiyaç- } \\
\text { lara ve gelişim düzeylerine sahip öğrencileri göz önünde bulundurarak İngilizce'yi eğlenceli ve ilgi } \\
\text { çekici hale getirmeyi, CEFR'in (Avrupa Dilleri Öğretimi Ortak Çerçeve Programı) çok dillilik ve } \\
\text { çok kültürlülük vurgusuna paralel olarak birçok uluslararası dil ve kültürü anlayıp değer verirken } \\
\text { aynı zamanda kendi kültürüne de önem vermeyi öğretmeyi öne çıkarmaktadır. } \\
\text { ISCED } 2 \text { Düzeyindeki Hedefler } \\
\text { - Öğrencilerin İngilizce öğrenmeye olan ilgilerini artırmak ve bu dili gerçek yaşamda kullana- } \\
\text { bilmelerini sağlamak. } \\
\text { - Öğrencilerin kültürel farklılıklar hakkında farkındalık geliştirmelerine yardımcı olmak. } \\
\text { - Öğrencilere dili sevdirmek, onların hedef dili eğlenerek öğrenmesini sağlamak ve dile karş1 } \\
\text { olumlu bir tutum geliştirmelerine yardımcı olmak. } \\
\text { - Dili bir amaç değil araç olarak kullanarak öğretmek, merak uyandırmak, dili öğrenmek ve kul- } \\
\text { lanmak için bir neden vermek. } \\
\text { Bunların yanı sıra, her bir kademe için spesifik kazanımlar belirlenmiş, ders kitaplarındaki temalara } \\
\text { uygun hedefler de ayrıca belirtilmiştir. Geliştirilmesi hedeflenen beceriler açısından öğrencilerin } \\
\text { seviyelerine uygun bir dağılım oluşturularak dört dil becerisine de (dinleme, konuşma, okuma ve } \\
\text { yazma) ağırlı verilmiştir. }\end{array}$ \\
\hline
\end{tabular}


Tablo 2'de de görüldüğü gibi; öğrencilerin İngilizce'yi kullanarak iletişim kurabilmeleri, günlük hayattaki olayları anlatan yazılı metinleri ve konuşmaları anlayabilmeleri, günlük yaşantılarını yabancı dilde aktarabilmeleri Finlandiya, Japonya, Kore, Çin (Şangay) ve Türkiye İngilizce öğretim programlarındaki hedeflerin ortak özellikleridir. Programların tümünde dört temel dil becerisi olan dinleme, konuşma, okuma ve yazmaya yer verildiği görülmektedir. Programlarda öne çıkan diğer bir unsur da kültürdür. Ülkelerin İngilizce öğretim programlarının tamamında kültürel bilinç oluşturmak, öğrenilen dilin kültürünü ve diğer kültürleri anlamak ve değer vermek vurgulanmaktadır.

Finlandiya ve Türkiye'de İngilizce öğretim programları hazırlanırken CEFR'de bulunan prensiplerin ve tanımlayıcıların dikkate alındığı, CEFR'de bulunan dil yeterlik ölçeğine göre kazanımlar ve hedefler yazıldığı görülmektedir. Ayrıca Japonya, İngilizce öğretim programında hedeflerin eğitim kademeleri açısından daha genel olduğu, öte yandan Finlandiya, Kore, Çin (Şangay) ve Türkiye'nin programlarındaki hedeflerin ve kazanımların daha detaylı bir şekilde betimlendiği anlaşılmaktadır.

\section{İngilizce Öğretim Programlarının İçerik Bakımından Karşılaştırılması}

İçerik, programın hedefleri doğrultusunda seçilmiş konular bütünüdür. Öğretim programlarının içerik boyutunda hedef-içerik ilişkisi kurulur ve hedefe ulaşmak için gereken bilgilerin aktarılması beklenir. Programın içerik boyutunda esas nokta içeriğin hedeflerle tutarlı olmasıdır.

Tablo 3. Finlandiya, Japonya, Kore, Çin (Şangay) ve Türkiye İngilizce Öğretim Programlarının İçerik Boyutlarının Karşılaştırılması

\begin{tabular}{|c|c|}
\hline 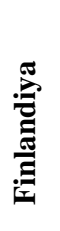 & $\begin{array}{l}\text { - Öğrencilere İngilizce'nin sunulacağ temel konular başlıklarla belirtilmiştir. (yakın çevre ve } \\
\text { aile fertleri; okul, okul arkadaşları ve öğretmenler, seyahat, hobiler..). } \\
\text { - Öğgrencilerin kendi kültürleri ve hedef dilin kültürüne ait bilgilerin de temalara dahil olduğu } \\
\text { görülmektedir. } \\
\text { - Öğgrencilerin kullandıkları dili gözlemlemeleri, etkileşimli ortamlarda alınan geri bildirimden } \\
\text { yararlanma, sözlü iletişimdeki bazı deyimleri kullanma gibi iletişim stratejilerine yer verilmiştir. }\end{array}$ \\
\hline 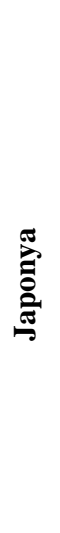 & $\begin{array}{l}\text { İçerik, (a) dil etkinlikleri, (b) dil etkinliklerinin tatbiki, (c) dilin ögeleri ve (d) dilin ögelerinin tatbiki } \\
\text { şeklinde dört kategoride belirlenmiştir. } \\
\text { - Dil etkinlikleri olarak ISCED } 2 \text { basamağının üç kademesine yayılmak üzere İngilizce'nin pra- } \\
\text { tikte kullanımını sağlamak için dört temel beceriye ait etkinlikler verilmiştir. } \\
\text { - Dil etkinliklerinin tatbiki için ise öğrencilerin gerçek hayatta sıkça karşılaşacakları durumlar } \\
\text { (ev yaşamı, okul yaşantısı, yerel faaliyetler..) ve öğretmenlerden sınıfta uygulamaları istenen } \\
\text { iletişimsel işlevler belirlenmiştir ve bunların uygulanmasında ISCED } 2 \text { nin her kademesi için } \\
\text { farklı etkinlikler yine belirlenmiştir. } \\
\text { - Programın hedeflerine ulaşmak üzere içeriğin ilk kısmındaki dil etkinliklerinde kullanılmak } \\
\text { için belirtilen dil ögeleri ise ses birimleri (fonemler), harfler, kelimeler, kalıplaşmış söz öbekleri, } \\
\text { yaygın ifadeler, dilbilgisel ögeler ve cümle yapıllarıdır. } \\
\text { - Son olarak bu dil ögelerini sınıf içinde doğru bir şekilde uygulamaya yönelik püf noktaları } \\
\text { verilmiştir. Dolayısıyla, programın içeriğinin dilin dört temel becerisini geliştirmeyi desteklemeye } \\
\text { yönelik hazırlandığı söylenebilir. }\end{array}$ \\
\hline ڤِ & $\begin{array}{l}\text { - İçerik, dört temel dil becerisini aşama aşama geliştirmeye ve bütünleştirmeye yönelik düzen- } \\
\text { lenmiştir. } \\
\text { - İçerik, iletişimsel etkinlikler üzerinde yoğunlaşmış ve bu etkinlikler fonetik ve yazılı etkinlikler } \\
\text { olarak gruplandırılmıştır. } \\
\text { - Kişileri tanıtma, takdir etme, vedalaşma, randevulaşma, davet etme, tebrik etme gibi iletişimsel } \\
\text { işlevler ve bu işlevleri gerçekleştirmeye yönelik kalıplara (Why don’t we meet at..., congratulations, } \\
\text { take care, this is my friend ...) fazlaca değinilmiştir. } \\
\text { - Her kademe için hedef söz varlığı belirlenmiştir. } \\
\text { - Programda verilen iletişimsel etkinliklerle beraber kullanılması önerilen gramer yapılarına da } \\
\text { yer verilmiştir. }\end{array}$ \\
\hline
\end{tabular}




\begin{tabular}{|c|c|}
\hline 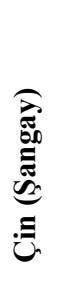 & $\begin{array}{l}\text { - İçerik, iletişimsel yeterlikleri geliştirmeye ağırlık vermekte ve dört dil becerisini de geliştirmeyi } \\
\text { hedeflemektedir. } \\
\text { - Programdaki son revizyon, öğrencileri öğrenmenin merkezine almış, onların uygun bağlam- } \\
\text { larda dili amaca uygun bir şekilde kullanmalarını teşvik etmeyi amaçlamıştır. } \\
\text { - Üniteler konu tabanlı olarak tasarlanmıştır ve günlük hayattan, öğrencilerin ilgilerini çekebile- } \\
\text { cek temalar üzerine üniteler inşa edilmiştir ve konular kültürel ögeleri de içermektedir. } \\
\text { - Ders içerikleri aynı zamanda döngüseldir ve öğretmenlere öğrencilerin seviye ve ihtiyaçlarına } \\
\text { göre içerik belirleme esnekliği sağlanmıştır. }\end{array}$ \\
\hline 齐 & $\begin{array}{l}\text { CEFR; dilin kullanımında akıcılığı, yeterliliği ve hatırlamayı desteklemesi bakımından öğrencile- } \\
\text { rin öğrendiklerini gerçek hayatta pratiğe dökmelerini özellikle vurgulamıştır (COE, 2001). } \\
\text { - Programın içeriği CEFR'in bu prensibine paralel olarak özgün iletişim ortamlarında İngi- } \\
\text { lizce'nin kullanılmasına ve dilin kendine ait yapısal bilgilerini kazanmaktan ziyade yabancı dili } \\
\text { belirli durumlarda kullanarak dil vasıtasıyla bir amacı gerçekleştirmeye yönelik hazırlanmıştır. } \\
\text { - Programda örnek olarak verilen ünitelerden anlaşıldığı üzere ünite tasarımında konu tabanlı } \\
\text { yaklaşım benimsenmiştir. } \\
\text { - Konuların içerisinde gerek öğrencilerin kendi kültürlerine, gerekse hedef kültür ve diğer kültür- } \\
\text { lere saygı duyma ve değer vermeyi sağlamak için kültürel unsurlar mevcuttur. } \\
\text { - Bütün kademelerdeki derslere ait her bir ünitede, kazandırılacak beceriler, iletişimsel işlevler, } \\
\text { öğretilmesi önerilen hedef söz varlığı, kullanılacak metin türleri (şiirler, diyaloglar, şarkılar..) ve } \\
\text { yapılacak etkinlikler (bağlamdan anlam çıarma, eşleştirme, simule etme, rol yapma...) ayrıntılı } \\
\text { olarak belirtilmiştir. }\end{array}$ \\
\hline
\end{tabular}

İçerik açısından ülkelerin programları incelendiğinde içeriklerin hedeflere uygun olarak programlarda yer aldığı, mevcut hedeflerin dilin iletişimsel boyutunu öne çıkardığını düşünürsek içeriklerin bu noktada hedeflerle örtüştüğü ve genel olarak dilin günlük hayatta kullanımını içeren etkinliklere içerikte yer verildiği, kültürel ögelerin de programlarda sıklıkla yer aldığı söylenebilir. Ayrıca, Finlandiya ve Türkiye'nin içerik ve konu tasarımında CEFR'in tayin etmiş olduğu prensipleri göz önünde bulundurduğu görülmektedir. İncelenen programlar arasında Finlandiya, içeriği en genel manada sunan programa sahiptir. Diğer ülkelerin öğretim programlarında her kademe için ayrı ayrı etkinlikler, iletişimsel işlevler, söz varlıkları vs. belirlenmişken, Finlandiya'nın programında ise içerik 1-2, 3-6 ve 7-9. kademeler için kısaca genel bir çerçeve olarak aktarılmıştır.

\section{İngilizce Öğretim Programlarının Öğrenme-Öğretme Süreci Bakımından Karşılaştırılması}

Öğrenme-öğretme sürecinde, programda belirlenen hedeflere uygun olarak hazırlanan içeriğin bireye hangi şekilde ve nasıl aktarılacağı söz konusudur. Dolayısıyla sınıf içi uygulamalarda kullanılacak olan araç-gereçler, öğretim yöntem ve tekniklerinin seçimi ve kullanımı programın süreç boyutu hakkında bilgi edinmemizi sağlar.

Tablo 4. Finlandiya, Japonya, Kore, Çin (Şangay) ve Türkiye İngilizce Öğretim Programlarının Öğrenme-Öğretme Süreci Bakımından Karşılaştırılması

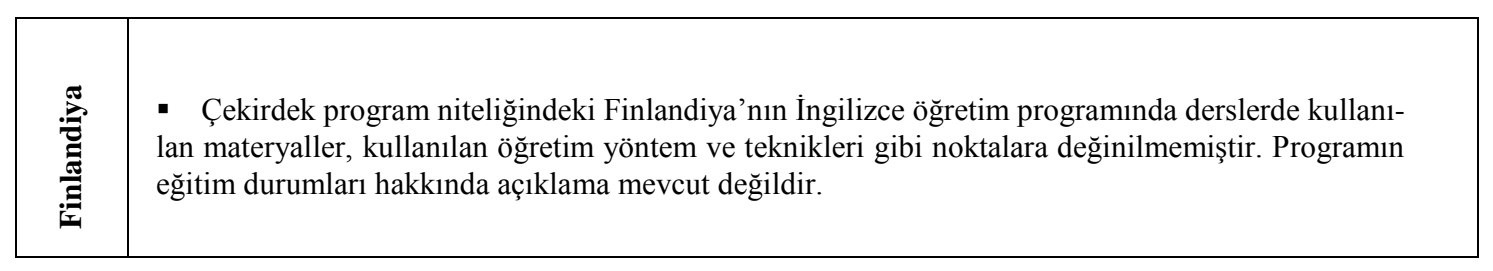




\begin{tabular}{|c|c|}
\hline 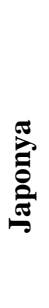 & $\begin{array}{l}\text { - Programın öğrenme-öğretme süreci boyutunda, içerik bölümündeki dilsel unsurların aşama } \\
\text { aşama ve kolaydan zora verilmesi gerektiğinin altı çizilmiştir. } \\
\text { - Sesletim ve söz varlığını geliştirmeye yönelik uygulama tavsiyeleri, kullanılacak materyallerin } \\
\text { hizmet etmesi gereken noktalar belirtilmiştir. } \\
\text { - İkili çalışma ve küme çalışması teşvik edilmekte; iletişim ağlarının ve bilgisayarın dil eğitimin- } \\
\text { de kullanımı ve ana dil olarak İngilizce konuşanlarla işbirliğinin önemi vurgulanmaktadır. } \\
\text { - Öğretmenlere, konu seçiminde göz önünde bulundurmaları gereken hususlar ve dilin özgün } \\
\text { ortamlarda işlevsel kullanımını sağlamaları önerilmiştir. }\end{array}$ \\
\hline بِ & $\begin{array}{l}\text { - Yürürlükteki İngilizce öğretim programında; uygulanan dil öğrenme ve öğretme tekniklerinin } \\
\text { öğrenciyi merkeze alması gerektiği, farklı öğrenme yeteneklerine sahip öğrencilerin dikkate alın- } \\
\text { ması ve öğrencilerin bağımsız şekilde kendi çalışmalarını başlatmaları vurgulanmaktadır. } \\
\text { - ISCED } 1 \text { düzeyinde sınıf içinde etkinliklerin nasıl uygulanacağının açıklanmasının yanı sıra öğ- } \\
\text { rencileri motive etmek için oyunların, çoklu ortam materyalleri, ve bilgi ve iletişim teknolojilerinin } \\
\text { (ICT) kullanımı, bireysel ve işbirlikli öğrenme yapılması önerilmiştir. } \\
\text { - ISCED } 2 \text { düzeyinde de öğrenci merkezli sınıf, dinleme becerisini geliştirmek için görsel-işitsel } \\
\text { materyal kullanımı, derslerin İngilizce olarak işlenmesi, bilgi ve iletişim teknolojilerinin kullanıl- } \\
\text { ması üzerinde durulmuştur. } \\
\text { - İletişimsel yaklaşımın (CLT) sınıf içinde uygulanması gerekliliğinin altı çizilmiştir. }\end{array}$ \\
\hline 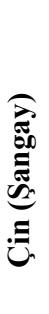 & $\begin{array}{l}\text { - Öğrenci merkezli, beceri odaklı ve iletişimsel hedeflere yönelik etkinlikler önerilmektedir. } \\
\text { - İçeriğin uygulamasında görev temelli ögretim de (Task-based Learning) önemli bir yer tutmak- } \\
\text { tadır. Öğrencilerin bu anlamlı görevleri tamamlamaları ve tamamlarken dili kullanmaları için } \\
\text { dersler görev öncesi, görev esnası ve görev sonrası şeklinde tasarlanmıştır. } \\
\text { - Bilgi aktarımı ve yeteneklerin geliştirilmesini dengelemek, yazılı ve sözlü çalışmayı bütün- } \\
\text { leştirmek, ikili ve küme çalışmalarını organize etmek ve öğrencilerin İngilizce’ de mümkün oldu- } \\
\text { ğunca çok iletişim ve etkileşim kurmaları için öğretmenlere eklektik yaklaşım kullanmaları öne- } \\
\text { rilmiştir. Ders materyalleri olarak bilgi ve iletişim teknolojileri de öğretimde önemli yer tutmaktadır. }\end{array}$ \\
\hline 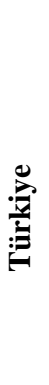 & $\begin{array}{l}\text { - Programda öğrencilerin iletişim aracı olarak İngilizce'yi tecrübe etmeleri adına, eylem odaklı } \\
\text { bir yaklaşım benimsenmiş, aynı anda birçok öğrenme stiline hitap etmek için ise tek bir dil öğretim } \\
\text { metodolojisinden ziyade, öğretimde eklektik bir yaklaşım benimsenmiştir. } \\
\text { - İngilizce'de iletişimsel yeterlik kazandırma hedefi doğrultusunda öğrencilerin sınıf içinde } \\
\text { yabancı dili bolca kullanmalarına yönelik iletişimsel ve işlevsel aktiviteler önerilmektedir. } \\
\text { - Öğrenci seviyesine ve dilin iletişim doğasına uygun olarak özgün materyaller, drama, rol yapma } \\
\text { ve uygulamalı etkinliklerin dil öğretimine entegrasyonunun sağlanması önemsenmiştir. } \\
\text { - Eğitimde üst kademelere çıktıkça basit ve bağlamsal aktivitelerden, zorlayıcı ve bağlamsal } \\
\text { görevlere geçilmektedir ve bu görevler öğrenen özerkliği ve problem çözme becerileri kazandır- } \\
\text { mayı da hedeflemektedir. }\end{array}$ \\
\hline
\end{tabular}

Son yıllarda birçok ülkede hazırlanan İngilizce öğretim programlarına baktığımız zaman, özellikle de "dil, iletişim içindir" düşüncesinin programlara yansıdığını görmekteyiz. Bu doğrultuda, programlar genelde yabancı dilin iletişim görevini öne çıkarmakta, etkinlikler yabancı dilin özgün iletişim ortamlarında etkin kullanımını sağlamayı amaçlamakta ve dilin yapısal birimlerinden ziyade dört temel dil becerisinin geliştirilmesi programlarda önemsenmektedir. Dolayısıyla, incelenen ülkelerden Finlandiya dışındaki Japonya, Kore, Çin (Şangay) ve Türkiye'deki programların süreç boyutunda da bu amaçlar öne çıkmış, bilgi ve iletişim teknolojileri, özgün materyaller ve çoklu ortam materyallerinin iletişimsel yaklaşımın özelliklerine paralel olarak kullanımı önemle vurgulanmıştır. Çekirdek program olan Finlandiya İngilizce öğretim programında öğrenme-öğretme sürecine yönelik bilgi mevcut değildir. Fakat belirlenen dil yeterlik düzeylerinin CEFR'i temel alarak düzenlenmesi ve de CEFR'in hedef dilin gerçek hayatta kullanılmasını (COE, 2001) özellikle vurgulaması Finlandiya' da eğitim durumlarında da iletişimsel etkinliklerin ağır bastığı izlenimini vermektedir.

Ayrıca Şangay'da okulların tercihi doğrultusunda, Avrupa Konseyi'nin resmî olarak destek- 
lediği CLIL (Content Language Integrated Learning) benzeri içerik temelli öğretim (CBEI) vasıtasıyla Matematik, Fen Bilgisi, Kimya gibi birçok dersin içeriği İngilizce olarak öğretilmektedir.

Bunun yanısıra, Çin'in genel eğitimde ve İngilizce eğitiminde parlayan yıldızı olan Şangay, ana dil olarak İngilizce konuşan İngilizce öğretmenlerini yurtdışından getirerek okullarında görevlendirmiştir. Kendi okullarındaki öğrencilerini kısa dönem pratik imkânı sağlamaları için ve İngilizce öğretmenlerini de meslekî gelişimleri doğrultusunda Avustralya ve Avrupa ülkelerine göndermektedir.

\section{İngilizce Öğretim Programlarının Sınama Durumları Bakımından Karşıllaştırılması}

Tablo 5. Finlandiya, Japonya, Kore, Çin (Şangay) ve Türkiye İngilizce Öğretim Programlarının Ölçme ve Değerlendirme Bakımından Karşılaştırılması

\begin{tabular}{|c|c|}
\hline 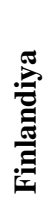 & $\begin{array}{l}\text { - Öğrencilerin dil yeterlik düzeylerini ölçmek üzere CEFR'deki tanımlayıcılar baz alınarak her } \\
\text { beceri için dil yeterlik çerçevesi belirlenmiştir. } \\
\text { • Değerlendirme günlük okul hayatının devam eden bir parçasıdır ve yıl boyunca her öğrenci } \\
\text { için en az bir gelişim raporu hazırlanır. Eğitimde süreç değerlendirilir; ve değerlendirmede öğret- } \\
\text { menler tarafından hazırlanan testler de uygulanır. (Eurydice). }\end{array}$ \\
\hline 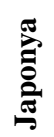 & $\begin{array}{l}\text { - Programda ISCED } 2 \text { düzeyi için öğrencilerin kazanması gereken hedef kelime sayısı, kalıp- } \\
\text { laşmış söz öbekleri, deyimler ve dilbilgisel ögeler belirlenmiştir. }\end{array}$ \\
\hline ڤِّ & $\begin{array}{l}\text { - Her basamak için dört temel beceriye ilişkin yapabilirlik ifadelerine (konuşmaların ana fikrini } \\
\text { kavrayabilir, yakınındaki bir kişiyi kısaca betimleyebilir...) yer verilmiştir. } \\
\text { - Portfolyo değerlendirme, öz değerlendirme ve akran değerlendirmesi önerilmiştir. } \\
\text { - Biçimlendirici (formatif) değerlendirme ile öğrenme yöntemlerinin uygunluğu kontrol edil- } \\
\text { melidir. ISCED 2'ye ait spesifik değerlendirme kılavuzunda ise dört temel becerinin değer- } \\
\text { lendirilmesi, analitik ve bütüncül bir değerlendirme yapılması, sık sık öğrenme hedeflerine ulaş1- } \\
\text { lıp ulaşılmadığının sınanması öne çıkmaktadır. }\end{array}$ \\
\hline 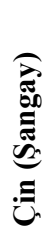 & $\begin{array}{l}\text { - Değerlendirmede amaç, değerlendirmenin seçme özelliğinden ziyade biçimlendirici ve yapı- } \\
\text { landırmacı işlevlerini ön plana çıkarmaktır. Gerçek hayattaki becerilerin sınanması ve daha fazla } \\
\text { açı uçlu sorular sorulması öne çımış̧ıtır. } \\
\text { • Özetleyici (summatif) değerlendirmeyle öğrencilerin nihai notunu almaktan ziyade, öğret- } \\
\text { menler her bir öğrenci için "Gelişim Kaydı Broşürü" gibi alternatif değerlendirme araçlarını } \\
\text { kullanarak öğrencilerin gelişimini izlemelidir. }\end{array}$ \\
\hline 文 & $\begin{array}{l}\text { - Öğrencilerin kendi gelişimlerini ve başarılarını gözlemleme imkânı veren ve CEFR'in de } \\
\text { prensipleri arasında yer alan “öz değerlendirme” önerilmektedir. "Bu ünitede neyi, ne kadar ög- } \\
\text { rendiniz, ögrendiklerinizle gerçek hayatta neleri yapabilirsiniz?" şeklinde öz değerlendirmeye } \\
\text { yönelik sorular mevcuttur. } \\
\text { • Öz değerlendirmenin yanında yazılı ve sözlü sınavlar, kısa sınavlar, projeler ve ev ödevleri } \\
\text { gibi resmî öğretimdeki ölçme-değerlendirme araçları da programda yer almaktadır. Bunların } \\
\text { yanında akran değerlendirmesi, portfolyo ve öğretmen gözlem ve değerlendirmeleri de sunul- } \\
\text { maktadır. } \\
\text { - Öğrencilerden ayrıca Avrupa Dil Portfolyosu'nda belirtilen "dosya” tutmaları istenmektedir. }\end{array}$ \\
\hline
\end{tabular}

Finlandiya İngilizce öğretim programında 3.-6. ve 7.-9. sınıflar için CEFR'deki ortak referans düzeylerine göre öğrencilerin dört temel becerilerde ulaşmaları gereken seviyeler belirlenmiştir. Eğitim durumlarında olduğu gibi sınama durumları açısından da programda bilgi mevcut değildir.

Japonya İngilizce öğretim programında öğrencilerin ISCED 2 düzeyinde eğitimlerini 
tamamladıkları zaman 1200 İngilizce kelime kazanmış olmaları hedeflenmiştir. Programda değerlendirmenin ne şekilde yapılacağına dair ibareler bulunmamaktadır. Japonya'da üniversitelerin bazı bölümlerine girmek için üniversite giriş sınavlarında İngilizce sorularını da çözmek gerekmektedir. Bu sorular dilbilgisi ağırlıklı hazırlanmaktadır. Bu da sınıf içindeki öğrenme sürecine ve dolayısıyla da değerlendirme etkinliklerine yansımaktadır. Öğrenciler de sınavın içeriği uyarınca okuma parçalarını anlama, dilbilgisi kuralları ve cümle yapılarına odaklandıkları için sözlü iletişim becerileri geri planda kalmaktadır.

Kore İngilizce öğretim programında, başarı ölçütleri olarak her bir düzey için ayrı ayrı öğrenilecek kelime sayıs1 ve kurabilecekleri cümle uzunluğu kriterleri belirlenmiştir. Örneğin, 4. sınıflar için hedef dilde ortalama 120 kelime kullanabilmeleri öngörülmüştür.

Şangay İngilizce öğretim programında öğrenciler için hedef dilde sayısal nitelikler de belirlenmiştir. Örneğin, ISCED 2 düzeyindeki eğitimlerini tamamladıktan sonra Şangaylı öğrencilerden dakikada 60 İngilizce kelime okumaları ve içerisinde \%2'den daha az bilmedikleri kelime olan metni \%70 doğrulukla anlamaları beklenmektedir.

Şangay'da son yıllarda üniversiteye giriş sınavında (NCEE) yapılan yabancı dil sınavının yanısıra öğretim programını esas alarak hazırlanan ISCED 1 ve ISCED 2 düzeyinde yabancı dil yeterlik sınavları da uygulanmaktadır. 5 farklı dereceden (Band 1-5) girilebilen bu sinavlar, üniversiteye girişte uygulanan yabancı dil sınavından daha fazla beceri odaklı olup, aynı zamanda konuşma ve dinleme becerilerini de ölçmektedir.

Türkiye'de uygulanan İngilizce öğretim programının (2.-8. sınıflar) dil öğretim seviyesi bakımından hedefi, öğrencilerin ISCED 2 düzeyinde eğitimlerini tamamladıktan sonra Avrupa Ortak Başvuru Metninin A1 ve A2 Düzeyi için belirlemiş olduğu genel kazanımlara ulaşmalarını sağlamaktır. Giriş ya da Keşif Düzeyi (A1) Ortak Yeti açıklamalarına göre; öğrenci sıradan ve gündelik deyişlerle somut gereksinimleri karşılamayı hedefleyen son derece yalın ifadeleri anlayabilir ve kullanabilir. Kendini veya bir başkasını tanıtabilir. Eğer kendisiyle konuşan kişi yavaş ve tane tane kendisine yardımcı olacak biçimde konuşuyorsa, basit bir biçimde iletişim kurabilir. Ara ya da Temel Gereksinim Düzeyi (A2) Ortak Yeti açılamalarına göre öğrenci tek cümleleri ve doğrudan öncelik alanlarıyla (sözgelimi yalın ve kişisel bilgiler ve aile bilgileri, alışverişler, yakın çevre, iş) ilişkili olarak sıklıkla kullanılan deyimleri anlayabilir. Bildik ve alışlagelen konular üzerinde yalnızca yalın ve dolaysız bilgi alışverişini gerektiren basit ve bildik etkinlikler çerçevesinde iletişim kurabilir. Eğitimini, dolaysız çevresini yalın yollardan betimleyebilir ve dolaysız gereksinimlerine denk düşen konuları anlatabilir (MEB., 2013).

Genel olarak ülkelerin programlarındaki sınama durumlarına baktığımız zaman Kore, Çin (Şangay) ve Türkiye'de hazırlanan İngilizce öğretim programlarındaki sınama durumlarının daha çağdaş bir yaklaşımla hazırlandığını ve alternatif değerlendirme yöntemlerinin önerildiğini görmekteyiz. Japonya'nın İngilizce öğretim programında ise alternatif değerlendirme yöntemlerinden ya da değerlendirme kriterlerinden detaylı ve net bir şekilde bahsedilmediği görülmektedir. Japonya'da İngilizce derslerinin okullarda ISCED 2 düzeyinde başladığını da düşünürsek dil eğitimine diğer pozitif bilimler kadar ağırlık verilmediği söylenebilir. Finlandiya'da ise sınıf içi uygulamalara ve sınama durumlarına yönelik öğretmenlere esneklik tanınmıştır. Her ne kadar programda değerlendirme araçlarına dair bilgilendirici ifadeler bulunmasa da öğrencilerin ölçülmek istenilen dil yeterlik düzeyleri CEFR'e göre hazırlandığı için CEFR'in öne çıkardığı alternatif değerlendirme yöntemlerinin kullanılıyor olması tabiîdir. 


\section{Sonuç}

Finlandiya, Japonya, Kore, Çin (Şangay) ve Türkiye'nin İngilizce öğretim programlarının karş1laştırıldığı bu çalışma programlar arasında hedef, içerik, eğitim durumları ve sınama durumları açısından benzerlik ve farklılıkları ortaya koymayı amaçlamıştır.

Finlandiya, Japonya, Kore, Çin (Şangay) ve Türkiye İngilizce öğretim programları "öğrencilere yabancı dilde iletişim becerileri kazandırmak" ve "kültürel farkındalı yaratarak hedef kültürü ve diğer kültürleri anlamak ve farklı kültürlere değer vermek" hedeflerinde birleşmektedirler.

Ülkeler arasında İngilizce'ye formal eğitimde başlama yaşı ve haftalık görülen İngilizce ders saatleri farklılık gösterse de, programlardaki eğitim faaliyetlerinin amacı temel olarak öğrencilerin hedef dilde iletişim kurabilmelerini sağlamaktır. Öğretmenlerin sınıf içindeki uygulamaları farklı olabilir; fakat incelenen İngilizce öğretim programları eğitim durumları açısından dilin alt becerilerinden biri olan dilbilgisi öğretiminden ziyade, dilin dört temel becerisi olan konușma, dinleme, okuma, yazma becerilerinin edinilmesine yöneliktir. Yine ülkelerin öğretim programları öğrenme-öğretme sürecinde öğrencinin aktif rol oynamasını, hedef dilin temel becerilerini geliştirerek dili günlük hayatta kullanmasını, dili iletişimsel yönüyle benimsemesini vurgulamışlardır. Bu bağlamda sınıf içi uygulamalarda iletişimsel işlevler, etkinlikler ve görevler öne çıkmıştır. Özgün materyaller, bilgi ve iletişim teknolojileri ve çoklu ortam materyallerinin iletişimsel yaklaşım doğrultusunda kullanılması Finlandiya dışındaki ülkelerin öğretim programlarında yer edinmiştir. Fakat Finlandiya'nın İngilizce öğretim programı "çekirdek program" özelliği taşıdığı için genel bir çerçeve sunmakta ve öğrenme-öğretme süreci ve kullanılması istenen materyallere dair bilgi sunmamaktadır.

Programların ölçme-değerlendirme boyutuna baktığımız zaman, Kore, Çin (Şangay) ve Türkiye İngilizce öğretim programları alternatif değerlendirme yöntemlerini ve değerlendirme sürecine öğrencilerin de katılabileceğini öne çıkarmıştır.

\section{Öneriler}

\section{Araștırmacılara Yönelik Öneriler}

1. Bu karşılaştırma çalışması, Finlandiya, Japonya, Kore, Çin (Şangay) ve Türkiye'nin İngilizce öğretim programlarını kapsamaktadır. Araştırmaya farklı kıtalardan farklı ülkeler de dahil edilebilir.

2. Ülkelerin İngilizce öğretim programlarındaki hedeflerle bu hedeflerin ne kadarına sınıf içi uygulamalarında ya da ülkeler bazında ulaşıldığının belirlenmesi bu tür çalışmaların boyutunu değiştirebilir.

3. Uluslararası özel eğitim ve istatistik kurumları dünya ülkeleri için Ingilizce Yeterlilik Endeksleri açıklamaktadırlar. Ülkelerin bu endeksteki sıralarının İngilizce öğretim programlarının yapısıyla ne derece ilişkili olduğu kapsamlı bir araştırmanın konusu olabilir.

4. Bu çalışmada ISCED 2 düzeyindeki İngilizce öğretim programları irdelenmiştir. Diğer düzeyde hazırlanan programlar da incelenebilir. Ayrıca, ülkelerin ana dillerine ait öğretim programları ya da farklı disiplinlere ait programlar da araştırılabilir.

\section{Uygulamacılara Yönelik Öneriler}

1. Programlarda özellikle altı çizilen iletişimsel etkinliklere sınıf içinde yer verilmelidir. Dil, tıpkı bir enstrüman çalmak gibi pratik yaptıkça gelişen bir araç olduğu için öğrenciler mutlak surette öğrenme sürecinde aktif kılınmalı, dili kullanmaları teşvik edilmeli, dili kullanmaları için sebepler yaratılmalıdır. İngilizce, öğretilecek bir ders olmaktan ziyade kazan- 
dırılacak bir beceri olarak görülmelidir.

2. Yabanc1 dil dersleri mevcut sınav sistemlerine kurban edilmemelidir. Öğrencilerin yıl sonunda girecekleri birtakım sınavlar dilbilgisi ve okuduğunu anlama ağırlıklı diye düşünerek, öğrencilere İngilizce iletişim becerilerinin kazandırılması geri plana itilmemelidir. Zira, günü kurtarmak yerine öğrencilerin gelecekte kazanacakları becerileri düşünmek daha pragmatik bir yaklaşım olacaktır.

3. Tipik kağıt kalem sınavları çoğu ülkede öğrencilerin İngilizce'deki kazanımlarının ölçülmesinde kullanılmaktadır. Fakat, konuşulan ve iletişim kurmaya yarayan bir enstrüman olarak dilin çoğu zaman yalnızca bu şekilde değerlendirilmesi garip bir durumdur. Dolayısıyla, konuşma ve dinleme becerilerinin dil sınıflarında hem öğretimin hem de değerlendirmenin odağında olması gerekmektedir.

\section{Program Geliştirenlere Yönelik Öneriler}

1. Geliştirilen İngilizce öğretim programlarında öğretmenlere sınama durumları açısından esneklik sağlanması, her ne kadar objektif değerlendirmeden uzaklaşmak gibi görünse de öğrencilerin sınav anındaki performanslarından ziyade süreç içerisindeki genel katkılarının değerlendirilmesi bakımından yararlı olacaktır.

2. Sesletim, öğrencilerin yabancı dil öğrenirken en çok sıkıntı çektikleri noktalardan biridir. Çoğu kez ana dil ile hedef dilin fonetik özellikleri benzerlik göstermemektedir. Bu noktada, program geliştirenler sesletim becerilerinin kazandırılmasına da programın öğrenme-öğretme boyutunda yer vermelidirler.

\section{KAYNAKÇA}

Atsuko, I., Yumi, M., \& Yoshiko, M. (2009). "English Education in Japan-From Kindergarten to University”. Ed. Reinelt, R. (2009). Into the Next Decade with (2nd) FL Teaching, 16-40. Rudolf Reinelt Research Laboratory EU Matsuyama, Japan.

Cenoz, J. (2003). "The Influence of Age on the Acquisition of English: General Proficiency, Attitudes and Code-Mixing”. Eds. Garcia, Mayo, M. P., \& Garcia, Lecumberri, M. L. Age and the acquisition of English as a Foreign Language, 77-93. Clevedon: Multilingual Matters.

Council of Europe (2001). “Common European Framework of Reference for Languages: Learning, Teaching, Assessment”. (CEFR).

Crystal, D. (2003). English as a Global Language. Cambridge University Press.

Dörnyei, Z. (2009). The Psychology of Second Language Acquisition. Oxford University Press. Education System of Finland. (n.d.). Retrieved from http://eacea.ec.europa.eu/education/eurydice/eurypedia_en.php.

Ellis, N. C. (2005). “Introduction to Part I: Acquisition”. Eds. Kroll, J. F., \& De Groot, A. M. B. Handbook of Bilingualism: Psycholinguistic Approaches, 3-8. Oxford. Oxford University Press.

Harmer, J. (2007). The Practice of English Language Teaching. London: Pearson Education.

Hu, G. (2005). "Reforms of Basic English-language Education in China: An Overview”. International Journal of Educational Reform, 14 (2), 140-165.

Hu, G. (2010). "Recent Important Developments in Secondary English-language Teaching in the People's Republic of China”. Language, Culture and Curriculum, 15 (1), 30-49.

Instructional System in Shanghai. (n.d.). Retrieved from http://www.ncee.org. (National College Entrance Examination).

Kachru, B. (1985). "Standards, Codification, and Sociolinguistic Realism: The English Language in the Outer Circle”. Eds. Quirk, Randolph, \& Widdowson, H. G. English in the World: Teaching and 
Learning the Language and Literatures, 11-30. Cambridge: Cambridge University Press.

Krashen, S. D., Long, M. A., \& Scarcella, R. C. (1979). "Age, Rate and Eventual Attainment in Second Language Acquisition”. TESOL Quarterly, 13, 573-582.

Kuhl, P. K. (2000). "A New View of Language Acquisition”. Proceedings of the National Academy of Sciences the United States of America (PNAS), 97/22, 11850-7.

Lightbown, P. M., \& Spada, N. (2006). How Languages are Learnt. Oxford: Oxford University Press.

McKay, S. L. (2000). "Teaching English as an International Language: Implications for Cultural Materials in the Classroom”. TESOL Journal, 9 (4), 7-11.

M.E.B. (2013). İlköğretim Kurumları (İlkokullar ve Ortakokullar) İngilizce Dersi Öğretim Programı, 2-8. Siniflar. Ankara: Milli Eğitim Basımevi.

Ministry of Education and Culture (2004). National Core Curriculum for Basic Education. Finland.

Ministry of Education, Culture, Sports, Science and Technology (2008). English Course of Study for lower secondary schools. Japan.

Ministry of Education, Science and Technology (2008). The School Curriculum of the Republic of Korea, English Curriculum. Korea.

Munoz, C. (2006). "The Effects of Age on Foreign Language Learning: The BAF Project”. Ed. C. Munoz. Age and the Rate of Foreign Language Learning, 1-40. Clevedon: Multilingual Matters.

Rajagopalan, K. (2004). “The Concept of World English and Its Implications for ELT”. ELT Journal, 58 (2).

Shanghai Municipal Education Commission (1998). Curriculum Guides for Primary and Secondary Schools in Shanghai.

Shanghai Curriculum and Teaching Materials Reform Commission. (1999). Program for $21^{\text {st }}$ CenturyOriented Reform on Foreign Language Curricula for Primary and Secondary Schools in Shanghai. Shanghai: Shanghai Education Press.

Stewart, T. (2009). “Will the New English Curriculum for 2013 work?”. The Language Teacher, 33 (11), 9-13.

Tahira, M. (2012). “Behind MEXT’s new Course of Study Guidelines”. The Language Teacher, 36 (3), 3-8.

Tan, C. (2012). "The Culture of Education Policy Making: Curriculum Reform in Shanghai”. Critical Studies in Education, 53 (2), 153-167.

Yıldırım, A., \& Şimşek, H. (2003). Sosyal Bilimlerde Nitel Araştırma Yöntemleri. Ankara: Seçkin. 